\title{
Mixed infecting of grapevine with viruses in the commercial vineyards of the Crimean Peninsula
}

\author{
Valentina Risovannaya ${ }^{*}$, Vitalii Volodin, YakovVolkov, Elena Stranishevskaya and Svitlana \\ Goryslavets
}

FSBSI All-Russian National Research Institute of Viticulture and Winemaking Magarach of the RAS, 31 Kirova Str., 298600 Yalta, Republic of Crimea

\begin{abstract}
Viral infections cause the reduction of yields and efficiency of vine cultivation in all viticultural regions of the world. Simultaneous infecting with several viruses, the so-called mixed infection, can significantly increase the severity of symptoms. The article presents the results of study of mixed infecting of grapevine with viruses in the vineyards of the Crimean Peninsula during 2011-2020. More than 800 grapevine samples of 153 varieties selected in 23 vineyards of the Crimea were analyzed over the entire period of study. Presence of phytopathogenic viruses in the samples was determined by RT-PCR using virus specific primers. The share of $25.5 \%$ of all the samples tested gave positive result for one or more of the following viruses: GFLV, GLRaV-1, GLRV-2, GLRaV-3, GFkV, GVA, GRSPaV, ArMV, GFLV. During the process of studyno vines affected by GVB virus were identified. Single-agent infection was found in $20 \%$ of the examined vines. The amount of vines affected by mixed infection was $5.48 \%$ of all tested. In a mixed viral infection more common combinations are: GRSPaV/GFkV; GVA/GRSPaV; GVA/GLRaV-1/GRSPaV; GVA/GLRaV-3/GRSPaV. Vines were infected the most with GRSPaV and GFkV viruses, which is visually manifested in the form of mosaic leaf variegation, leaf chlorosis and the appearance of necrotic spots.
\end{abstract}

\section{Introduction}

Viral diseases of grapes are widespread throughout all viticultural regions of the world. Damage to the vineyards caused by viral infections leads to a decrease in the yield and quality of grapes. Viruses disrupt various aspects of plant metabolism, such as photosynthesis, transfer of respiration assimilants, depress plant growth and development, reduce winter survival, drought resistance of the vine, its life cycle, etc. Infection with phytopathogens directly affects the quality of wine, causing economic damage to the industry $[1,2]$.One of the ways of spreading pathogens of grape diseases, reproduced vegetatively, is a direct transit of infection from the mother plant to its offspring, being a source of infection of the planting material for new plantations [3,4]. Phytosanitary

\footnotetext{
${ }^{*}$ Corresponding author: MGR.Magarach@gmail.com
} 
examinations of vineyards reveal plants infected with both single viruses and mixed infections, i.e. simultaneously infected with two or more pathogens.

Phytopathogens causing mixed infections can be microorganisms in combinations of the type: virus - virus, virus - bacterium, bacterium - fungus, etc. More than 60 different species of viruses and viroids damaging commercial vineyards have been found in the grapevine. The most common and dangerous viral infections of grapevine include: grapevine fan leaf virus(GFLV), grapevine fleck virus $(\mathrm{GFkV})$, grapevine leafroll-associated virus 1 (GLRaV1), grapevine leafroll- associated virus $2(\mathrm{GLRaV}-2)$, grapevine leafroll-associated virus 3 (GLRaV-3), Arabis mosaic virus (ArMV), corking of grape bark (Grapevine virus A, GVA), grapevine wood pitting (Grapevine virus B, GVB) and Rupestris stem pittingassociated virus(GRSPaV). Grapevines affected by these viruses possess the abnormal external features: rolling and discoloration of leaves, double nodes, shortened internodes, fasciations of shoots, bunches, tendrils and butts, growth retardation of bushes, unfertile shoots, pitting on vine trunk, sometimes on arms and roots, etc. [1-6].

It was found that some viruses causing grape diseases were part of different pathogen complexes, for example, infectious degeneration (fanleaf) is apparently caused by a complex of viruses, including grapevine fan leaf virus, Arabis mosaic virus, tomato ringspot virus, tomato bushy stunt virus and supposedly tobacco mosaic virus. Of cause, there are other viruses as well. Their complexity degree varies depending on the vineyard and composition of cultivated varieties [7]. Grapevine leafroll virus is often found in combination with many other viruses and is well known in many parts of the world $[5,7,8]$. The complexes found so far, for example, in California, included, in addition to the grape leafroll virus, fan leaf virus, yellow vein virus, ring spot virus and corking virus of grape bark. During a survey of 99 vines from the United States of America and Europe, viral infections were detected in 46 selected varieties of Vitis vinifera, $V$. labrusca and interspecific hybrids. Most of the vines were infected with single-agent viruses, and 16 were mixed infected with viruses of Betaflexiviridae, Closteroviridae, Secoviridae and Tymoviridae families [5,9].

It is known that simultaneous infection with several viruses can significantly increase the severity of symptoms. Studies show that infection is often associated with reduced cropping capacity and quality of grape juice, decreasing of soluble solids and higher titratable acidity. Other qualitative parameters, that can be changed by viral infection, are the amount of aromatic compounds in muscadine and phenolic substances in red grapes $[2,10,11]$. An important technological parameter for winemaking is the thickness of berry skin together with the strength of its breaking, associated with extractability of phenolic substances from skin $[10,12]$. Mixed infections with GFLV and GFkV, as well as GLRaV-3 and GVA, were causing changes in mechanical properties of the berry skin, most pronounced with thickening of the skin, which reduced the amount of phenols extracted from these berries. This is especially important for grape varieties that have poor anthocyanin berry profile, which mainly affects the intensity and color stability of wine. Mixed grapevine infection with GFLV and GFkV, GLRaV-1 and GVA, or GLRaV-3 and GVA can seriously affect the quantity and quality of the crop yield in different ways, depending on the viruses involved. Thus, the grape leafroll-associated virus (GLRaV-1, GLRaV-2, GLRaV-3) is often found in combination with many other viruses, for example, with stem pitting-associated complex (GRSP) and corking of grape bark (GVA) and negatively effects the efficiency of reproduction both in vivo and in vitro [13]. It was shown that viral infections reduce the vigor of vine growth, especially in plants infected with GFLV and GFkV, less with GLRaV3 and GVA [3,14-15]. Thus, the affection of grapevine by viral infection reduces the efficiency of cultivation and negatively impacts the quality parameters of wine and table grapes, simultaneous infection of the plant with several 
viruses can significantly increase the severity of symptoms. In this regard, the purpose of our research is to study mixed viral infection that occurs in the vineyards of Crimea.

\section{Materials and Methods}

\subsection{Selection of grape plant material}

Sampling on grape were carried out of grape plantations in 23 farms of different grape zones of Crimea: Alushta district, Bakhchisarai district, region of Sevastopol city (Sevastopol zone), Simferopol district, Sudak district, Yalta district. Grapevine leaves and shoots with external symptoms of viral diseases were selected for the study. Examinations and samplings of plants were carried out in accordance with EPPO recommendations (2010) [16].

Selected and aboriginal grape varieties growing in the vineyards of Crimeawere studied. In total,more than 800 grapevine samples of 46 varieties were analyzed. All samples were tested by RT-PCR for latent form of viruses: grapevine fan leaf virus(GFLV), grapevine fleck virus $(\mathrm{GFkV})$, grapevine leafroll-associated virus $1(\mathrm{GLRaV}-1)$, grapevine leafroll associated virus 2(GLRaV-2), grapevine leafroll-associated virus 3(GLRaV-3), Arabis mosaic virus(ArMV), corking of grape bark (Grapevine virus A, GVA), grapevine wood pitting (Grapevine virus B, GVB ), Rupestris stem pitting-associated virus (GRSPaV).

\subsection{RNA and PCR extraction}

RNA was extracted by the method of Rott and Jelkman [17] or using the CytoSorb kit (Syntol) from grape leaf and phloem. To synthesize the first cDNA chain, reverse transcription kits (Syntol, Eurogen, Russia) were used in accordance with the manufacturer's manuals. Classical PCR and multiplex PCR were used. To carry out multiplex PCR, a 2.5X reaction mix (Syntol) or a 5X Screen mix (Eurogen) with primers specific for each virus was used. Multiplex PCR included: GLRaV-2 / GLRaV-3 / GFkV; GVB / GVA / GRSPaV; ArMV / GLRaV-1 / GFLV. Internal positive control RNA (18S rRNA) (844 bps) was used as an indicator of RNA quality and RT-PCR efficiency. Visualization of the results of multiplex PCR was performed by gel-electrophoresis method.

\section{Results}

Of all samples tested over the entire study period, $25.5 \%$ gave positive result for one or more of the following viruses: GFLV, GLRaV-1, GLRV-2, GLRaV-3, GFkV, GVA, GRSPaV. (Fig. 1, a-c). 


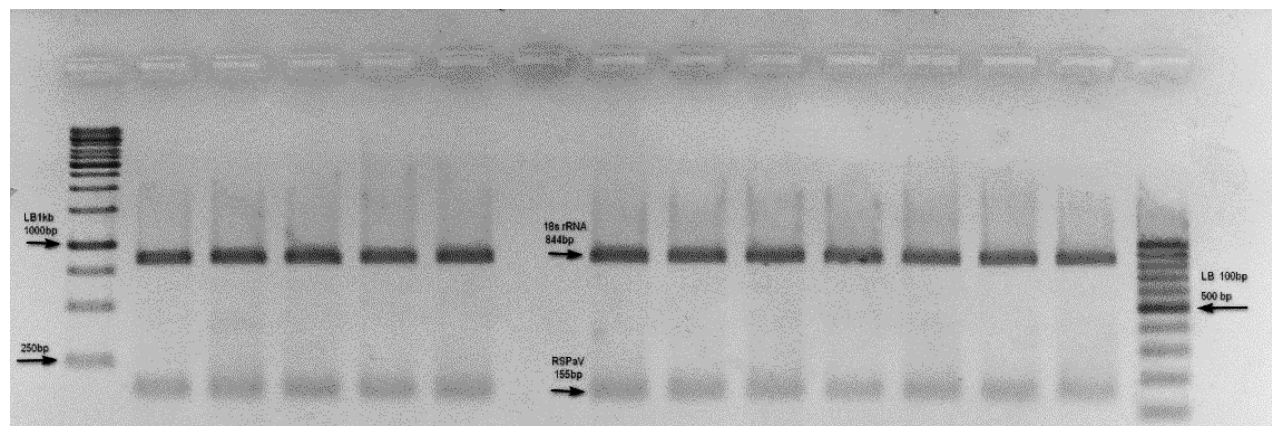

a

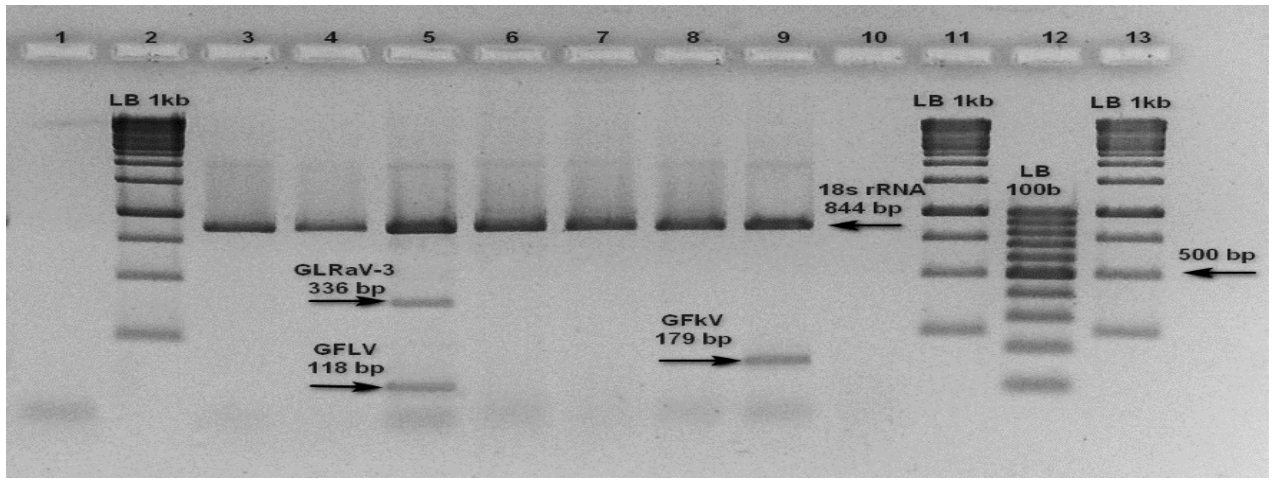

b

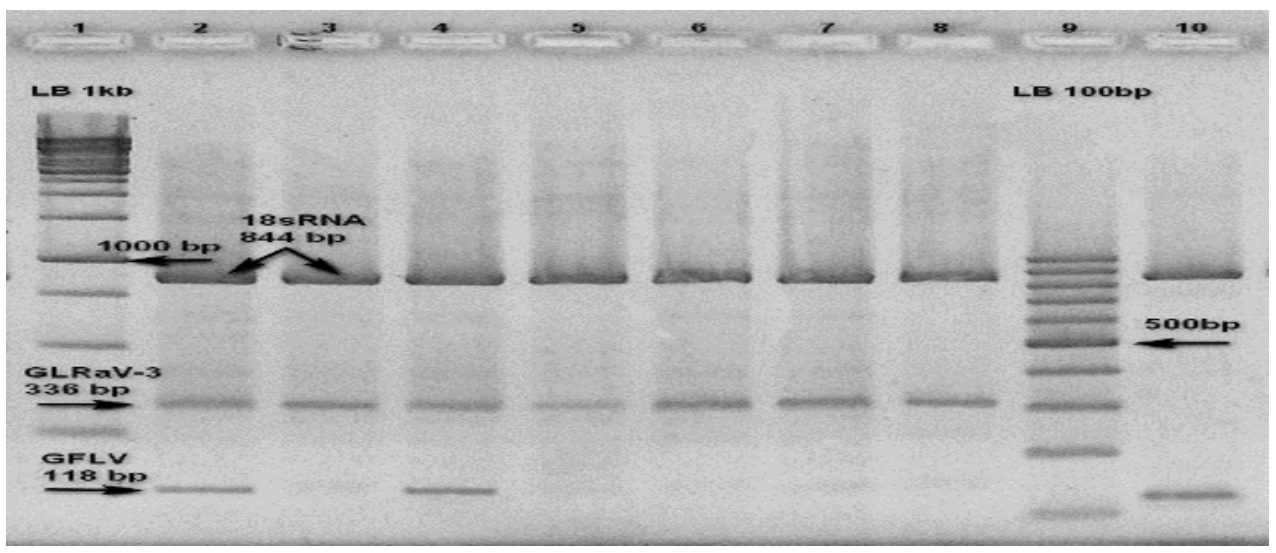

C

Fig. 1.The example of multiplex PCR electrophoregrams for virus identification:

a) No.1 - LB 1kb; No. 2-8, samples, infected with virusGRSPaV (155 bps); No.6 - OK; No.15 - LB 100bps; Internal Positive Control (IPC) - 18s rRNA (844 bps);

b) No.2, 11, 13 - LB 1kb; No.12 - LB 100bps; No.1, 10 - OK; No. 3, 6, 7 - samples with no viruses detected; No.5 - mixed infection detected - GLRaV-3 (336 bps) and GFLV (118 bps);No.7 -virus GFkV detected (179bps);

c)No.1- LB 1 kb; No.9 - LB 100 bps; No.3, 5-8 - samples, infected with virus GLRaV-3 (336 bps); No.10 -fan leaf virus GFLV detected (118 bps); No.2,4 - mixed infection detected - GLRaV-3 (336 bps) and GFLV (118 bps) 
No vines affected by GVB virus were identified during the study. Single-agent infection was found in $20 \%$ of the examined vines (Fig. 1.a). The vines were mostly infected with GFkV and GRSPaV viruses, which amounts $83.2 \%$ of the total number of infected samples, and the least with GLRaV-2 (2.3\%), GLRaV-1 (2.8\%) and ArMV (1.4\%)(Fig. 2).

$\Delta$

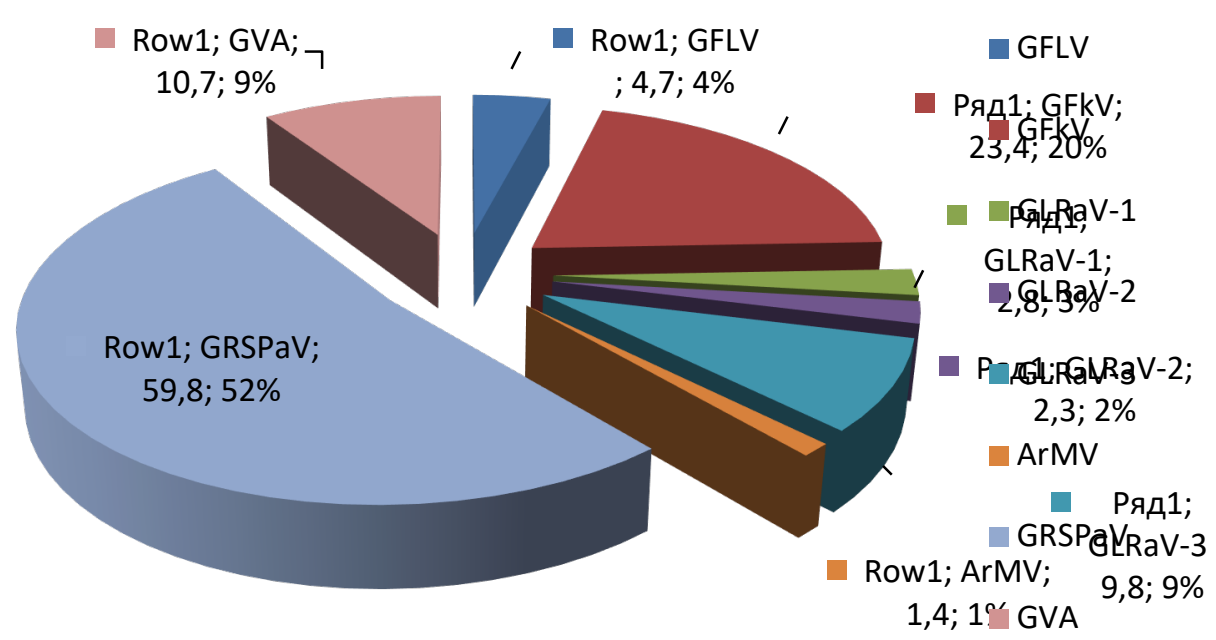

Fig. 2. Species composition of viral infection in $\%$ of all the infected vines

In some vineyards, the species composition of viral infection ranged from 1 to 5 viruses. Some vines were mix infected (Table 1).

Table 1. Variants of mixed viral infection found in the vineyards of Crimea

\begin{tabular}{|l|l|}
\hline Virus & mixedinfectionwith: \\
\hline GRSPaV & GFkV, GLRaV-3, GLRaV-2, GLRaV-1, GVA, GFLV \\
\hline GVA & GLRaV-1, GRSPaV, GLRaV-3, GFLV, GLRaV-2 \\
\hline GFLV & GRSPaV, GLRaV-3, GVA \\
\hline GLRaV-1 & GVA, GRSPaV \\
\hline GLRaV-2 & GRSPaV, GLRaV-3, GVA \\
\hline GLRaV-3 & GVA, GRSPaV, GFkV, GLRaV-2, GFLV \\
\hline GFkV & GRSPaV, GLRaV-3 \\
\hline
\end{tabular}

Vines with two, three and four viruses isolated together were identified in the vineyards surveyed. The number of vines affected by mixed infection was $5.48 \%$ of all the tested. We identified 13 variants of mixed infection, including 9 variants containing two viruses, 2 variants of mixed infection containing three viruses, and 2 variants of mixed infection containing four viruses (Fig. 3). 


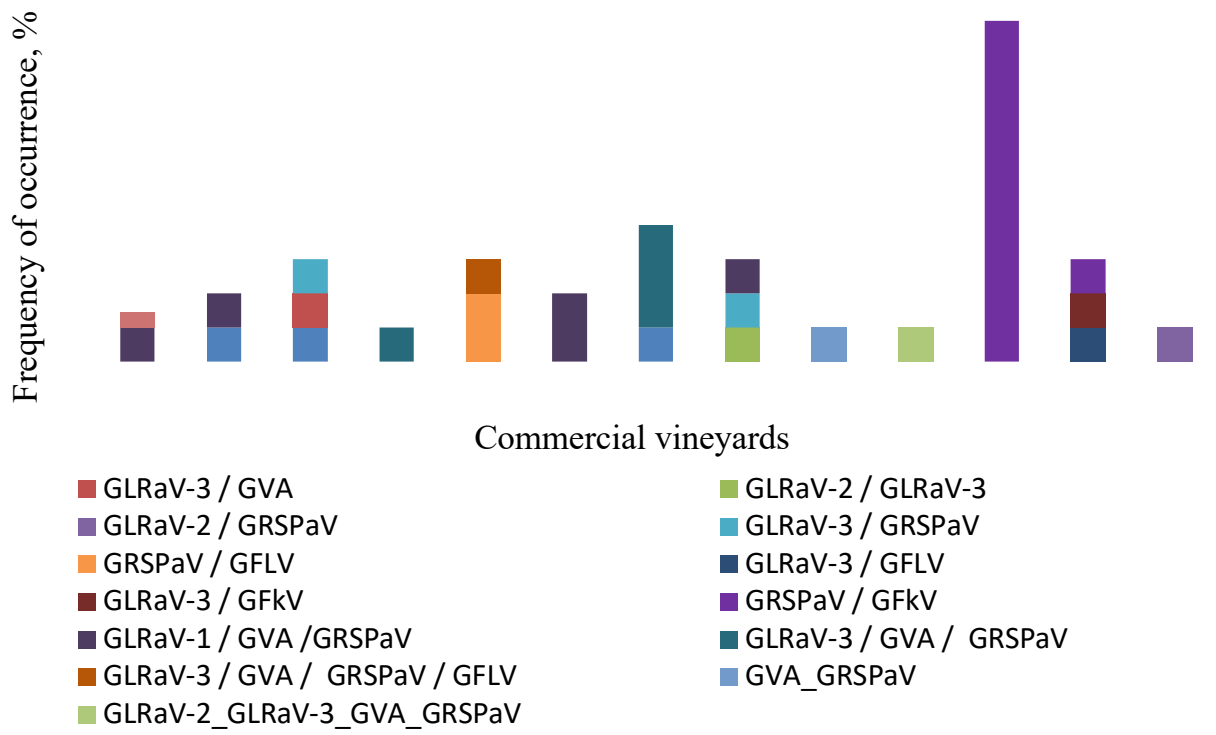

Fig.3.Variants of mixed infection distribution in the farms of Crimea

Identification of grape viruses by the method of RT-PCR showed that the most common combination of mixed viral infection is GRSPaV / GFkV (23.9\%), which is visually manifested in the form of mosaic leaf variegation, leaf chlorosis and the appearance of necrotic spots (Fig. 4).
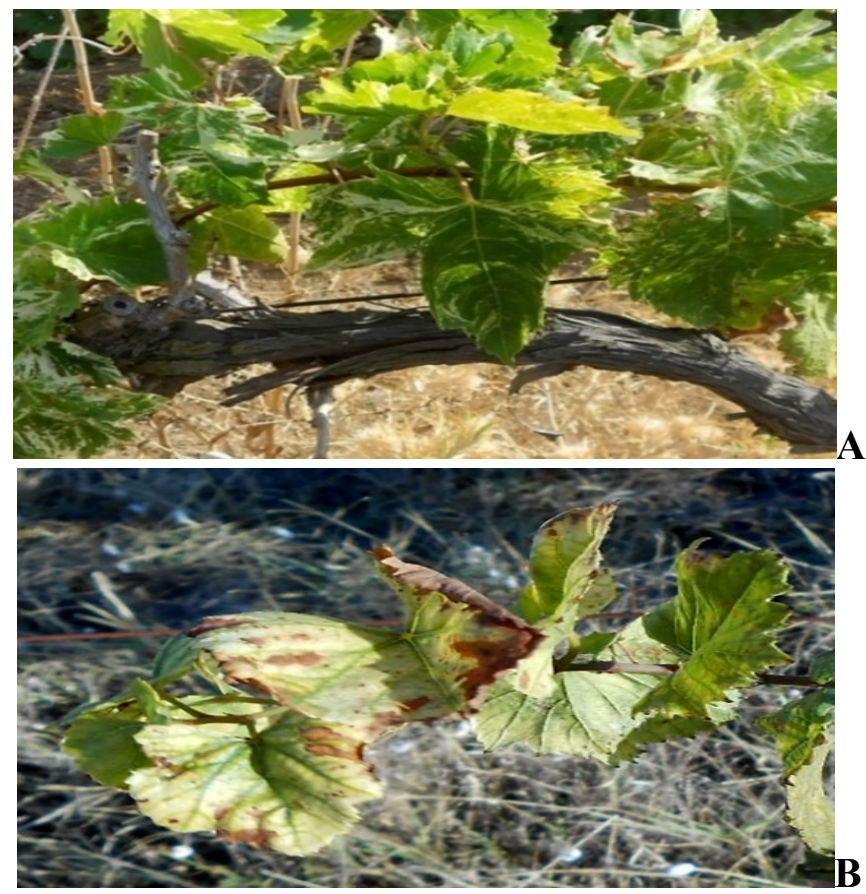

Fig.4.Mosaicvariegation (a) and leaf chlorosis and necrotic spots (b) with mixed infection $\mathrm{GRSPaV}+\mathrm{GFkV}$ on grapes 
Grapevines affected by the remaining 12 variants of mixed infection ranged from 2.17 $\%$ to $6.52 \%$. Distribution of mixed viral infection in the examined Crimean vineyards was not equal. In six vineyards, vines were affected by one variant of mixed infection: GVA/GRSPaV, GLRaV-2/GRSPaV, GLRaV-2/GLRaV-3, GLRaV-1 /GVA/GRSPaV, GLRaV-3 /GVA/GRSPaVиGLRaV-2/ GLRaV-3/ GVA / GRSPaV. In other vineyards vines were infected with several variants of mixed infection.

\section{Conclusion}

The studies conducted make it possible to identify the species composition and distribution of viruses in the commercial vineyards of the Crimean Peninsula. As a result the following viruses were identified: GFLV, GLRaV-1, GLRV-2, GLRaV-3, GFkV, GVA, GRSPaV and ArMV. Identification of grape viruses showed that the most common combinations of mixed viral infection are: GRSPaV/ GFkV; GVA/ GRSPaV; GVA/GLRaV-1/ GRSPaV; GVA/GLRaV-3/GRSPaV. The frequency of occurrence of viroses caused by the remaining 9 variants of mixed infection was insignificant.

Presence of viral phytopathogens, especially mixed infections, suggests that using of infected planting material for vineyards and the lack of system monitoring of its movement could play an important role in the spread of viruses. Our studies demonstrate the effectiveness of multiplex detection of grape viruses. Characteristics of associations of the most pathogenic viruses will help to understand their effect on the grape plant and will be useful in certification of planting material for establishment of vineyards.

\section{References}

1. 1. B. Meng, G. P Martelli. D. A. Golino, M. Fuchs. Grapevine Viruses: Molecular Biology, Diagnostics and Management; Springer: Heidelberg, Germany, 31-46 (2017). https://link.springer.com/book/10.1007\%2F978-3-319-57706-7

2. F. Mannini, M. Digiaro. In Grapevine Viruses: Molecular Biology, Diagnostics and Management Springer:AG, Chapter 23. 453-482 (2017). https://link.springer.com/chapter/10.1007\%2F978-3-319-57706-7_23

3. V. I. Maliogka, G. P. Martelli, M. F Katis, N. I. Katis. Adv. in Virus Res. 91, 175-227 (2015). https://www.sciencedirect.com/science/article/pii/S0065352714000098?via\%3 Dihub

4. A. V. Zherdev, S. V. Vinogradova, N. A. Byzova, E. V. Porotikova, A. M. Kamionskaya, B. B. Dzantiev, Agric., 8, 195 (2018). https://doi.org/10.3390/ agriculture812019

5. R. Naidu, A. Rowhani, M. Fuchs, D. Golino, and G. P Martelli, Plant Dis., 98 (9), 1172 - 1185 (2014). https://apsjournals.apsnet.org/doi/10.1094/PDIS-08-13-0880-FE

6. V Mondello, A. Songy, E. Battiston, C. Pinto, C. Coppin, P. Trotel-Aziz, C. Clément, L. Mugnai, F. Fontaine, Plant Dis., 102, 1189-1217 (2018). https://apsjournals.apsnet.org/doi/10.1094/PDIS-08-17-1181-FE

7. A. Jooste, N. Molenaar, H. J Maree, R. Bester, L. Morey, W. C De Koker, J. T Burger, $\begin{array}{llllll}\text { Europ. J. } & \text { 142(2), } & \text { 127-144 } & \text { (2015). }\end{array}$ https://ink.springer.com/article/10.1007\%2Fs10658-015-0620-0

8. N. Bertazzon, M. Borgo, S.Vanin, E. Angelini. Eur. J. Plant Pathol., 127, 185-197 (2010). https://www.semanticscholar.org/paper/Genetic-variability-and-pathologicalproperties-of-Bertazzon-Borgo/3898002a19230e58050117cf4a192bf8afa9b9e9

9. M .J. Melzer, D. M. Sehter, W. B. Borth, E. F. Mersino, HU J. S. Virus Genes, 42, 254-260 (2011). https://doi.org/10.1007/s11262-010-0537-9 
10. D. Santini, L. Roll, P. Cascio , F. Mannini, S. Afr. J. Enol. Vitic., 32 (2), 183-189 (2011). https://www.journals.ac.za/index.php/sajev/article/view/1378

11. L. R. Gutha, L. F. Casassa, J. F. Harbertson, R. A. Naidu, BMC Plant Biol., 10, 187 (2010). https://doi.org/10.1186/1471-2229-10-187

12. S. Río Segade, S. Giacosa, V. Gerbi, L. Rolle,. LWT-Food Sci. Technol. 44, 392-398 (2011). https://www.sciencedirect.com/science/article/pii/S0023643810003063?via $\% 3$ Dihub

13. M. Tobar, N. Fiore ,A.G. Pérez-Donoso, R León, I. M. Rosales, M. Gambardella, Hortic. Res., 7(2), 3-14 (2020). https://www.nature.com/articles/s41438-019-0224-5

14. S.T. Endeshaw, P. Sabbatini, G. Romanazzi, A.C. Schilder, D. Neri, D., .Sci. Hortic., 170, 228-236 (2014). https://www.sciencedirect.com/science/article/abs/pii/ S0304423814001344?via\%3Dihub

15. 15.K. D. Ricketts, M. I. Gomez, S. S. Atallah, M. Fuchs, T. E. Martinson, M. C. Battany, L .J. Bettiga, M. L.Cooper, P. S. Verdegaal, Smith R J. Am J Enol Vitic., 66, 138-47 (2015). https://www.ajevonline.org/content/66/2/138

16. OEPP/EPPO: Sertification scheme patogen-tested material of grapevine varieties and rootstocks. PM 4/1-26 (2010). http://www.furs.si/law/eppo/seme/ENG/Vinska_trta_ certifikacija.pdf

17. E. V. Porotikova, V. I. Risovannaya, Y. A. Volkov, U. D. Dmitrenko, V. A. Volodin, S. M. Gorislavets, E. P. Stranishevskaya, A. A. Agranovsky, A. M. Kamionskaya, S. V. Vinogradova. Moscow University Biological Sciences bulletin 71 (2), 76-79 (2016). https://doi.org/10.3103/S0096392516020097

18. G. Gambino, D. Cuozzo, M. Fasoli, C. Pagliarani, M. Vitali, P. Boccacci, M. Pezzotti, F. Mannini, J. Exp. Bot. 63 (16), 5919-5933, (2012). https://doi.org/10.1093/j xb/ers244 